\title{
Study of Slum Area Environmental Carrying Capacity for the Happiness of Slum Household Family Life (Case Study of Gender and Ecological Perspectives)
}

\author{
Sitti Nursetiawati ${ }^{*}$, Dian Pertiwi Josua ${ }^{2}$ \\ \{*sitti-nursetiawati@unj.ac.id ${ }^{1}$,dian_pertiwijoshua@apps.ipb.ac.id² $\}$
}

\begin{abstract}
State University of Jakarta, Faculty of Engineering, Cosmetology Studies Program, Indonesia ${ }^{1}$, IPB University, Faculty of Human Ecology, Family and Child Development Studies, Indonesia ${ }^{2}$
\end{abstract}

\begin{abstract}
Adequate housing areas are difficult to find, especially in urban areas. At present, slums are an option for families to live and settle on the grounds of the lack of availability of a proper environment. There have been a lot of studies on the environment and happiness, but those that refer to happiness based on family units, and gender, are still few. This study is a joint study, with the aim of analyzing the influence of the environment in slums on the happiness of families who live in the area. This research involved 30 families, and differentiated happiness according to sex, which was based on the perspective of the father, mother, and children of one family. This research was conducted in the East Pisangan area, East Jakarta. Sources of research data sourced from primary data and secondary data. Primary data were obtained through the Oxford Happiness Questionnaire filled out by respondents based on their own reports, while secondary data came from interviews and observations. The results of the study stated that: (a) The environment affects the happiness of family slums, (b) Communities in slums have quite high happiness conditions, and (c) there are differences in happiness between men and women in slums.
\end{abstract}

Keywords: Ecological analysis, family happiness, gender studies, and the slum environment.

\section{Introduction}

DKI Jakarta Province has an area of $662.33 \mathrm{~km} 2$ and is inhabited by $10,177,924$ people, and the population of its inhabitants is relatively inadequate, both in terms of regional conditions and environmental health. There are 115 slum villages in DKI Jakarta Province, one of which is Pisangan Timur Village, Pulo Gadung District, East Jakarta. Problems with slums in Jakarta, including; (a) $40 \%$ of buildings inhabited by irregular residents, $9 \%$ of buildings did not meet the eligibility requirements in terms of roofs, floors and walls, (b) $22 \%$ of residential areas did not have adequate road access, (c) $26 \%$ of poor drainage, (d) $14 \%$ of the community does not meet their water needs of at least $60 \% /$ person / day, (e) $5 \%$ of houses do not have latrines or closets connected to septic tanks, $87 \%$ of household sewage in the form of water, mixed with environmental drainage, (f) $22 \%$ of household waste is transported to the TPS / TPA menu less than 2 times a week, and (g) 89\% of settlements are 
not equipped with fire protection infrastructure or facilities (Ministry of Public Works and Public Housing, 2017) [1].

The problems of slum households are motivated by economic problems and are related to health, food consumption, security, and other subjective and objective welfare issues. One indicator of subjective well-being which is psychological well-being is happiness. United Nation issued the World Happiness Report (2019) [2] and said that Indonesia is a country with a 92 nd happiness rating out of 156 countries in the world. Happiness is seen from the income earned by citizens, freedom, trust, healthy life expectancy, social support, and kindness or generosity.

The data on the level of happiness assesses that the happiness of Indonesian people has increased from what was originally in the 96th position in 2018, to 92th in 2019. Indonesia's happiness index in 2019 was also stated to have increased from 5,093 to 5,192 points. Methods of measuring the index of happiness seen based on money (index score 62.99), position (index score 67.15), family harmony (index score 80.05), social relationships (index score 75.45), positive relationships with others (index score 71.93), health (index score 71.12), security (index score 77.15) and feelings of pleasure (index score 75.06).

The survey on happiness in Indonesia was also carried out by the method of measuring the happiness index on the dimensions of life satisfaction (index score 71.07), feeling dimensions (index score 68.59), and life meaning index (index score 72.23). The happiness index indicator states that Indonesians feel the most dissatisfied with their level of education and achievement (index score 59.90). As for happiness as measured through the level of satisfaction, the most important factors considered happy in Indonesia are family harmony (index score 80.05) and environmental conditions (index point 76.09) (BPS, 2017) [3]. Therefore, it is considered important to conduct an analytical study of the environmental carrying capacity of slums towards the happiness of family life of slum households according to gender and ecological factors.

Looking at the background that has been presented, the formulation of the problem of this research is, (a) the carrying capacity of conditions in a slum household environment, and (b) the happiness of a slum household family life. Referring to this background, this study aims to (a) examine the environment of slums, and (b) analyze the influence of environmental carrying capacity on the happiness of the lives of families living in slums.

\section{Literacy Study}

\subsection{Slum Household}

Slums are defined as settlements that are not suitable for habitation because of irregular buildings, high levels of barriers and buildings, and the quality of buildings, facilities, and infrastructure that do not meet the requirements (Law No. 1 of 2001). Slum households have indicators of weighting criteria for low building resilience, access to drinking water and inadequate sanitation, and sufficient living area $\leq 7.2 \mathrm{~m} 2$ (Susenas, 2017) [4].

BPS (2016) mentions slum households in urban areas, which have the following characteristics, (a) The population is the lowest $40 \%$ expenditure group, (b) does not have access to adequate sources of drinking water, (c) Has no access to proper sanitation, (d) Do not have access to floor area $\leq 7.2 \mathrm{~m} 2$ percapita, (e) Do not have access to adequate roof, floor and wall conditions. 
The condition of slum households in East Pisangan Village, has problems which are indicators of slums, these problems include; (a) $34.5 \%$ of houses were built irregularly, and $17.6 \%$ of buildings with roofs, floors, walls did not meet technical requirements, (b) $38.8 \%$ of residential areas did not have a network of access roads, (c) $22.2 \%$ of drainage in poor condition, (d) $25.0 \%$ of the community's water needs are not met, which is as much as $60 \%$ / person / day, (e) $3.3 \%$ of residential residential buildings do not have a toilet with a septic tank, $100 \%$ of household sewage drains mixed with environmental drainage, (f) $29.8 \%$ of domestic household waste in residential areas are transported to TPS / TPA less than 2 times a week, (g) 100\% of settlements do not have protection on fire facilities and infrastructure (Ministry of Public Works and Public Housing, 2017) [1].

The environment plays an important role in one's life. Environmental problems such as lack of facilities, noise, air pollution, and social crime can affect people's health and happiness. The environment is divided into two types, namely the physical environment such as structures and buildings and the social environment in the form of relationships and developments among citizens including honesty, trustworthiness, and cooperation (Abdullah and Zulkifli, 2018) [5]. Based on studies conducted several core characteristics of urban life with reference to a certain size and density contribute negatively to happiness, which can be interpreted as dense and the slums of the environment can reduce happiness (OkuliczKozaryn, and Mazelis, 2018) [6].

\subsection{Happiness}

Psychologists say that naturally and instinctively, humans always struggle for happiness, they want to be happy and will maintain the happiness they want. Human effort in achieving happiness has two sides positive and negative goals. On the positive side, happiness aims to eliminate pain and displeasure, while on the negative side, happiness is the feeling of wanting very strong pleasures (Freud, 1930) [7]. Happiness can also be interpreted as, (a) Temporary emotions that are synonymous with feelings of joy, (b) Experience fulfillment and achievement characterized by cognitive evaluation, (c) The long-term process of making meaning and developing identity by way of achieving individual potential and the pursuit of goals that are subjectively relevant (Fave et al., 2011) [8].

The theory of happiness, says that happiness is 3 basic views, namely: (a) Hedonism, happiness is a process of experiencing firsthand, as a whole, most of the pleasure, or so-called Hedonia, (b) The view of life satisfaction, where to be happy, one needs have a pleasant attitude about his life either as a whole or only in a certain period of time, known as Eudaimonia, (c) Affective state theory, that happiness depends on overall human emotions (Heybron, 2003) [9]. Psychology views happiness and divides happiness into three types; (a) Pleasure and satisfaction, (b) Embodiment of strength and virtue, and (c) Meaning and purpose (Seligman, 2018) [10]. Meanwhile, a survey measuring the level of happiness (SPTK) of Indonesia, seen based on three dimensions namely, (a) Life satisfaction, (b) Feelings (affect), and (c) The meaning of life (Eudaimonia).

People who live in urban areas, especially in urban areas, are always correlated with the level of happiness and life satisfaction. The happiness index, which is usually measured by other studies, is mostly focused on the environment (Kešeljević and Spruk, 2013) [11]. This study, complements the existing research, with the different units studied, that in this study looks at happiness based on the perspective of each family member, and the focus of the research is on gender and ecology. In addition, there is still little research about linking happiness to the physical environment. 


\section{Research Methods}

This research is a cross-sectional study. The research location was taken purposively based on the area studied which is a slum area according to data from the Ministry of Public Works and Public Housing (2017) [1]. The study population was an intact family with at least 1 child in it living in a slum household area. This research was conducted in the Pisangan Timur area, East Jakarta. Before conducting field trips, researchers used a tool in the form of Google Earth to observe the research area and to be able to see a portrait of the slums to be examined as a whole. Samples were taken as many as 30 families purposively. The total sample in this study was 90 people, namely 30 fathers, 30 mothers, 15 daughters, and 15 sons. The study was conducted on qualitatively and quantitatively. Data analysis techniques through descriptive and inferential analysis techniques.

Descriptive analysis is processed using Microsoft Excel to see the results of observations of slum households. Inferencing analysis includes a different independent sample t-test to see differences in the happiness of family members according to sex, as well as an influence test using a regression test processed with SPSS to see the environmental influences and happiness of families living in slums.

\section{Results and Discussion}

Environmental conditions examined in this study include physical and non-physical conditions that can affect family happiness. On the environmental carrying capacity variable, the data is taken through a process of observation and self-report questionnaires regarding respondents' satisfaction with the slum households that they live in. As for the happiness variable, it was taken using the Oxford Happiness Questionnaire tool filled by each family member (Father/Husband, Mother/Wife, and one child). Physical environmental conditions in the study, as a whole were seen using Google Earth (See figure 1).

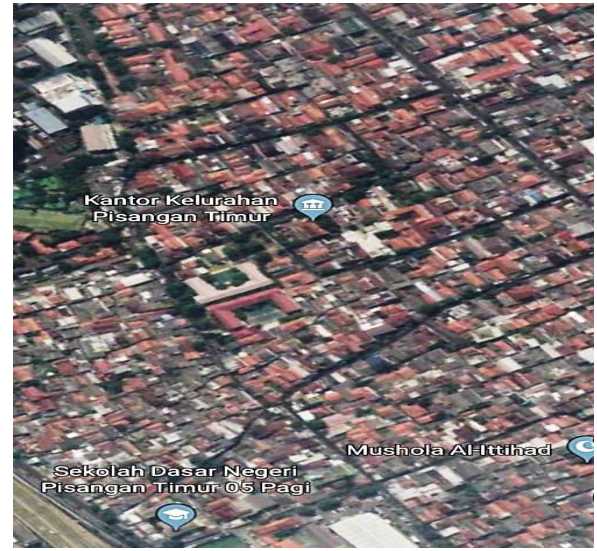

Fig. 1. Environmental density and congestion as indicators of slum environment of the study site 


\subsection{Physical Environmental}

Conditions Floor area, yard, the distance between houses and the number of rooms. The results related to floor area show that the floor area of the house most inhabited by children in high-density family environments is 20-29 $\mathrm{m} 2$ with a floor area of 50-69 $\mathrm{m} 2$. The home page in the study shows a picture that there is no distance between one house and another. For the number of rooms, the average slum household has three to four rooms in one house.

Floor area is too narrow, causing children and parents to sleep in the same room so that it causes children to mature too quickly, and other influences are sexual interactions that are out of place, do not have adequate space for social interaction, and the absence privacy in family members. In this dirty household, the boundaries between rooms are unclear and only limited to a piece of cloth, cupboard, or pile of goods. The absence of a home page causes the child does not have a place to play, which impacts the child playing on the highway.

The results related to the floor area show that the floor area of the house most inhabited by children in high-density family environments is 20-29 $\mathrm{m} 2$ with a floor area of 50$69 \mathrm{~m} 2$. The home page in the study shows a picture that there is no distance between one house and another. For the number of rooms, the average slum household has three to four rooms in one house.

Building Type. The results showed that $67 \%$ of slum households in the study were of permanent type in small size, this was due to the influence of the family's economic level which was classified as low so it was difficult to build permanent houses that were livable.

Building Materials. The results of the study show that in a high-density home environment, building materials use cement to stir the floor material, the walls are half-walled, and the roof is in the form of ordinary roof tiles with the addition of plastic zinc. The remaining $24 \%$, slum households in the study environment use better building materials, namely in the form of tiles, tiles for flooring, the walls are already in the form of walls, the roof is made of tiles.

House Ventilation. Based on the results of the study, stated that air ventilation is generally inadequate, especially the condition of the house is too tight between one house with another house, the distance between houses is narrow and there is no air circulation. The only place for ventilation holes is on the roof. This inadequate ventilation endangers its inhabitants because polluted air contains germs that emanate from internal residents of the house from inhaled dust, touch, germs or bacteria from other household items. The close to house land, the lack of ventilation, and the high level of density of occupants in the house, cause oxygen (O2) of the house air to be reduced a lot, because it is consumed by many people so that respondents complain of being weak, shortness of breath, increased body temperature, dizziness and achy aches in the joints. 
Natural Lighting/Sunlight. The results of the study showed that there was not much sunlight coming into the house, due to the limited occupancy of land and no houses, so there was no distance between houses to other houses, people who lived in this slum household lived coexistent. Sunlight that contains ultraviolet $\mathrm{X}$ rays to reduce the humidity of the air in the house, kill the germs at a certain temperature, as well as activate the process of breeding the disease to a certain temperature. Due to the narrow floor of the house and the lack of air ventilation and associated with the sun's function as lighting during the day, generally, the children in the study area do not use the house to do many activities so that children prefer to play with their friends outside the home.

Water Sources. The results of the study stated, for the purposes of drinking water and toilets (Toilet Washing Toilet), dirty households in the study site used PDAM water, and as many as $74 \%$ of households chose to consume refill water without brands for consumption because PDAM water was yellowish.

Sanitation. Generally, slum households in the study have dirty drains, uncomfortable bathrooms, and latrines. Waterways are stagnant and clogged, often causing unpleasant odors, and flicking. While the bathroom and WC use a closed bathroom.

Household Waste. Based on the results of the study, residents at this location dispose of household waste in public garbage bins. The availability of trash bins is already private, using plastic bags and sacks for the disposal media for each household. The Final Disposal Site (TPA), coordinated by the head of the Rukun Tetangga (RT), then once a week the cleaning staff will help divert household waste to the general landfill.

Population Health. The results of the study indicate that the types of diseases that are often suffered by residents in the form of mild flu, aches in several parts of the body, and other diseases that are normal with normal frequency. There were no infectious diseases in the community environment at the study site.

Another result of the study is the condition of road access which can only be used for one type of vehicle from one direction, namely in the form of a motorcycle or bicycle, whereas for a car road is inadequate. Likewise, with the condition of gutters or waterways, it looks quite dirty and the house with one other house has no gaps.

\subsection{Non-Physical Environmental}

Conditions of Parents' Education. The results of the study showed that the average level of education of my father was junior high and high school. The low level of education results in the inability of the head of the family to understand that a slum household environment will have a negative impact on both the psychological and physical conditions of each family member. Other research results, states that the average education of mothers, namely vocational high school and high school, the low level of mother's education also contributes to the low awareness and environmental cleanliness of slum households. 
Parents' Work. The results of the study stated that most of the fathers at the study site worked in the informal sector as traders (food, drinks, children's toys, and building materials). The other types of Father's work are administrative staff, day laborers, workshop workers, online motorcycle taxi drivers, and public transport drivers. In relation to the work of mothers, most of the mothers in slum households are housewives.

Economic Condition. The study data shows that the average amount of expenditure in the study location is Rp. 170,000 per day with the type of expenditure is for education, food, housing, paying for household goods, installments to buy land or houses in other places, and vehicles in the form of motorbikes. However, based on the results of the interview, families in this slum household, trying to be able to set aside money for savings in understanding forms that will later be used as investment in children's education, health care costs, and other unexpected costs.

Parents' Leisure. Time The results of the study stated that most of the time mothers are housewives, can be more freely used to take care of, and care for the household, including in educating children. The majority of families confess, that Dad's work that takes up a lot of time, encourages children to interact more often with Mother than Father.

Number of Life. Dependents and Length of Stay Research data shows the number of family members per household is 3-5 people. Meanwhile, the length of stay of the nuclear family is 6-10 years. Most residents are sedentary, with housing ownership being the right to private or long-term contracting.

Happiness. This research shows that in families living in slums, wives are happier than husbands. On the contrary, in children who live in slums, boys feel happier than girls (See tables 1 and 2). In addition, the influence test states that the physical environment (beta $=$ 0.510 ), has a significant positive effect on happiness.

Table 1. Achievements based on husband and wife happiness

\begin{tabular}{lccccc}
\hline Variable & \multicolumn{2}{c}{ Husband } & \multicolumn{2}{c}{ Wife } & $\begin{array}{c}P- \\
\text { Min-Maks } \\
(0-100)\end{array}$ \\
\cline { 2 - 5 } & Mean \pm Std & $\begin{array}{c}\text { Min-Maks } \\
(0-100)\end{array}$ & Mean \pm Std & value \\
\hline Happiness & $50.00-72.00$ & $44.56 \pm 5.19$ & $53.00-75.00$ & $48.51 \pm 6.69$ & $0.013^{*}$ \\
\hline Note: $\left.{ }^{* *}\right)$ significance of $\left.0.01 ;{ }^{*}\right)$ & 0.05 significance & &
\end{tabular}

Table 2. Achievements based on the happiness of boys and girls

\begin{tabular}{|c|c|c|c|c|c|}
\hline \multirow[b]{2}{*}{ Varible } & \multicolumn{2}{|c|}{ Boys } & \multicolumn{2}{|c|}{ Girl } & \multirow{2}{*}{$\begin{array}{c}P- \\
\text { value }\end{array}$} \\
\hline & $\begin{array}{c}\text { Min-Maks } \\
(0-100)\end{array}$ & Mean \pm Std & $\begin{array}{c}\text { Min-Maks } \\
(0-100)\end{array}$ & Mean \pm Std & \\
\hline Happiness & $60.00-87.00$ & $75.11 \pm 6.66$ & $60.00-80.00$ & $69.17 \pm 7.04$ & $0.018^{*}$ \\
\hline
\end{tabular}

This means that each increase of 1 unit of the physical environment will increase the happiness of families living in slums by 0.510 , and each increase of 1 unit of non-physical 
environment quality will increase happiness by 0.344 points. Adjusted R Square value indicates that the model explains $32.4 \%$ of the influence of the variables studied in the happiness variable, the remaining $67.6 \%$ is influenced by other variables not examined (See table 3).

Table 3. Results of Regression Test Between Variables Researched

\begin{tabular}{|c|c|c|c|c|c|}
\hline No & Variable & $\begin{array}{c}\text { Beta } \\
\text { Unstandardized }\end{array}$ & $\begin{array}{c}\text { Std } \\
\text { Error } \\
\end{array}$ & $\begin{array}{c}\text { Beta } \\
\text { Standardized } \\
\end{array}$ & Sig. \\
\hline & Constanta & -19.208 & 13.644 & & 0.155 \\
\hline 1. & $\begin{array}{l}\text { Physical } \\
\text { environment }\end{array}$ & 0.510 & 0.126 & 0.428 & 0.000 \\
\hline 2. & $\begin{array}{l}\text { Non-physical } \\
\text { environment }\end{array}$ & 0.344 & 0.186 & 0.220 & 0.031 \\
\hline
\end{tabular}

Adjusted R Square: 0.324

Other results in the study show that the reasons why households continue to choose to live in slums are inherited culture and internalization of a culture of goodness that is already thick, in addition to the low economic factors and low family income, encouraging households to retain their homes, even though classified as a slum environment (Figure 2).

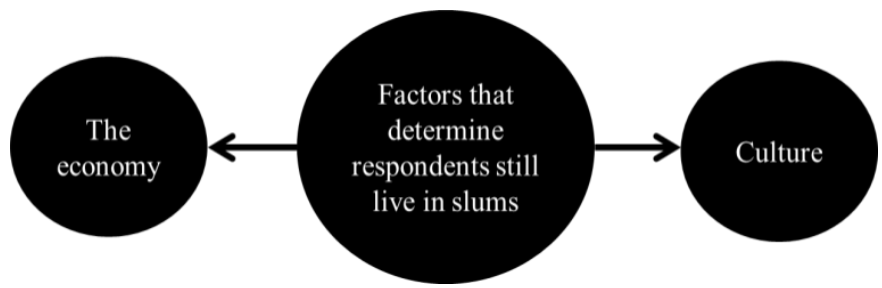

Fig. 2. The results of the interview of household factors choose to live in a slum environment

Regarding the reasons for happiness felt by slum households, there are two things that keep them happy. The reasons are in the form of internal reasons and external reasons. Internally, happiness comes because of high religiosity and great gratitude. External factors that encourage slum households to remain happy living in unfavorable environments is because they want to continue to inherit cultures from their ancestors, and because of the kindness and tolerance between neighbors that makes them assume that happiness is present not only seen in the physical environment only (Figure 3 ).

Religiosity is one of the internal factors that encourage respondents' happiness, this reinforces previous research that philosophically beliefs and religions are the backgrounds of happiness because happiness is not only about emotions and feelings. According to other studies that people who live in hunger with high poverty rates, and inadequate physical environments, in countries that still feel happiness, this proves that religion and belief in God will bring happiness (Diener, Tay, and Myers, 2011) [12].

The results of the research that have been mentioned, contrary to studies that have been done before, which states that high levels of happiness do not depend on environmental degradation (Tiwari and Mutaschu, 2015) [13]. Instead, this study reinforces research that says that humans who spend their time in a good physical environment, will improve their psychological well-being, one of which will feel happier. In addition, physical environmental 
factors, including green areas, community spatial planning, and social services affect human happiness (Chen and Zhang, 2018) [14].

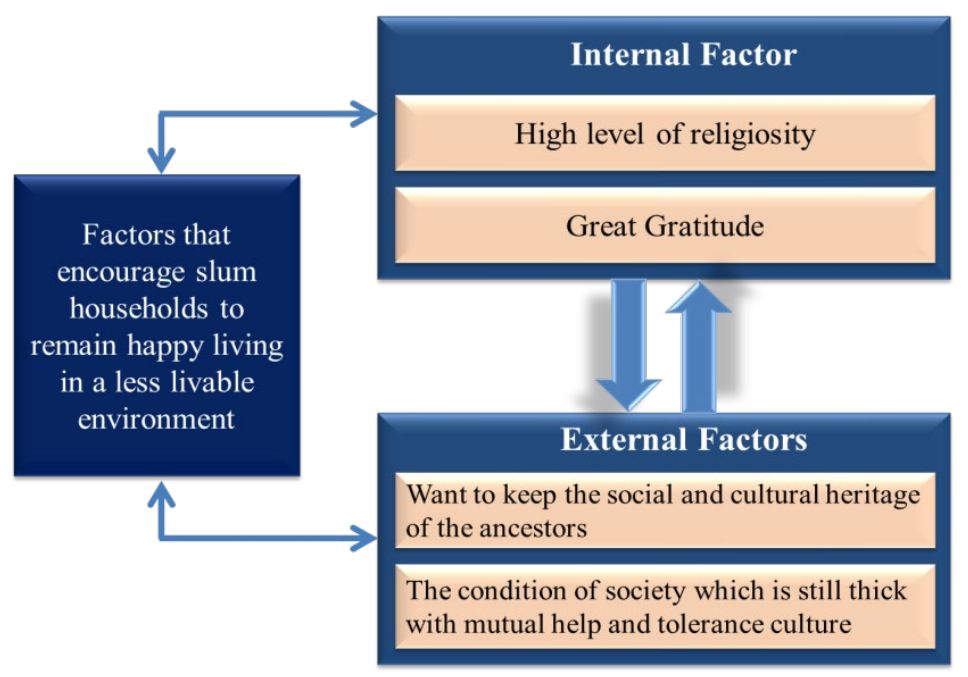

Fig. 3. The happiness factor in a slum environment

Happiness and the environment are said to be closely related to each other, this refers to Aristotle's happiness theory which explains that the happiness of life is a virtue which is a reciprocal process between humans giving goodness to others, and he will receive goodness from that environment. Greek philosophers based on the theory of 'Eudaimonia' founded by Aristotle believed that the definition of happiness is happiness achieved by humans through well-being or contentment and that happiness is an act that reflects one's well-being (Kenny, 2014) [15].

Components of the environment that can bring happiness between each human being will differ in perceptions and ideas, however, when the environment provides a sense of comfort even without having to refer to the physical environment, the residents will feel happy. Because the environment, can bring positive impacts and negative feelings for those who live and settle in it (Abdullah and Zulkifli, 2018).

\section{Conclusions and Suggestions}

Based on the results of the study it can be concluded that: (1) physical and nonphysical environment affects the happiness of families living in slums, (2) there are differences in happiness between husband and wife who live in slums, where wives more happy than husband, (3) in boys living in slums, happiness is higher than in girls. Suggestions that can be given to several parties include: (1) the government is expected to be able to expand the program to eradicate slums, and (2) for NGOs there is a need for volunteers who can complete facilities and infrastructure in slum households to build a non-slum environment physically in order to increase family happiness in a dirty household. 


\section{References}

[1] Ministry of Public Works and Public Housing. (2017). Profile of Jakarta slums.

[2] Helliwell, J. F., Huang, H., \& Wang, S. Changing World Happiness. World Happiness Report 2019.

[3] Statistik, B. P. (2018). Happiness index 2017. https://www. bps. go. id/, 16-03.

[4] Statistik, B. P. (2017). Susenas.

[5] Abdullah, Y. A., \& Zulkifli, F. L. (2018). A Conceptual Paper on the Theory of Happiness in Neighbourhood. Asian Journal of Behavioural Studies, 3(12), 1-12.

[6] Okulicz-Kozaryn, A., \& Mazelis, J. M. (2018). Urbanism and happiness: A test of Wirth's theory of urban life. Urban Studies, 55(2), 349-364.

[7] Freud, S. (1961). _.(1930). Civilization and its discontents. The standard edition of the complete psychological works of Sigmund Freud, 21, 57-145.

[8] Delle Fave, A., Brdar, I., Freire, T., Vella-Brodrick, D., \& Wissing, M. P. (2011). The eudaimonic and hedonic components of happiness: Qualitative and quantitative findings. Social Indicators Research, 100(2), 185-207.

[9] Haybron, D. M. (2003). What do we want from a theory of happiness?. Metaphilosophy, 34(3), 305-329.

[10] Seligman, M. (2018). PERMA and the building blocks of well-being. The Journal of Positive Psychology, 13(4), 333-335.

[11] Kešeljević, A., \& Spruk, R. (2013). Endogenous economic freedom and the wealth of nations: evidence from a panel of countries, 1996-2011. Applied Economics, 45(28), 3952-3962.

[12] Diener, E., Tay, L., \& Myers, D. G. (2011). The religion paradox: If religion makes people happy, why are so many dropping out?. Journal of personality and social psychology, 101(6), 1278.

[13] Tiwari, A. and Mutascu, M. (2015), "The relationship between environmental degradation and happiness in 23 developed contemporary economies", Management of Environmental Quality, Vol. 26 No. 2, pp. 301-321. https://doi.org/10.1108/MEQ-05-2014-0077

[14] Chen, C. L., \& Zhang, H. (2018). Do You Live Happily? Exploring the Impact of Physical Environment on Residents' Sense of Happiness. In IOP Conference Series: Earth and Environmental Science (Vol. 112, No. 1, p. 012012). IOP Publishing.

[15] Kenny, S. A. J. P. (2014). Aristotle. Encyclopaedia Britannica. Available at: http://academic.eb.com.ezaccess.library.uitm.edu.my/EBchecked/topic/34560/Aristole. Retrieved: May 2015. 